\section{Peirce and Education, an Overview}

Torill Strand ${ }^{1}$ and Catherine W. Legg ${ }^{2}$

${ }^{1}$ Department of Education, University of Oslo, Oslo, Norway

${ }^{2}$ Philosophy Program,

Deakin University,

Burwood, VIC, Australia

\section{Synonyms}

Edusemiotics; Phenomenology; Pragmatism; Semiosis; Semiotics

\section{Introduction}

The philosophy of Charles S. Peirce (1839-1914) enhances our understanding of educational processes. Peirce was the founder of American pragmatism, which today is a many-faceted branch of philosophy characterized by a critique of abstractions, traditional dichotomies such as mind and body, and metaphysical absolutes. At the turn of the last century, William James' lectures on pragmatism (1907) won an enthusiastic response, and "pragmatism" soon became a popular stance among American policy-makers and experts who celebrated its practical and resultoriented aspects. However, as a philosophical position, pragmatism differs from its widespread usage among politicians and pundits.

To Peirce, pragmatism was a guiding principle and method of accurate thinking which helps us to "make our ideas clear." Taking the mutual mediation of theory and praxis, knowledge and action, and facts and values into account, Peirce embraced concrete experience as not only philosophically relevant but our concepts' ultimate purport. A Peircean outlook on education thus helps us recognize ways in which the dynamics of knowledge and learning are inescapably rooted in, and a vital part of, situated experience. Moreover, while recognizing the social, experiential, and provisional character of knowledge and beliefs, Peirce also promoted a broad, teleological scientific ethos that may help to clarify and rectify many mainstream educational beliefs and much habitual thinking. However, Peirce's most valuable contribution to education could turn out to be his semiotics - a study of the meaning and development of signs which enables us to conceptualize and explore all communicative processes in terms of sign relations and sign actions.

\section{Experience and Education}

Peirce places phenomenology as the primary and initial branch of philosophy, since philosophy "does not busy itself with gathering facts, but merely with learning what can be learned from 
that experience which presses in upon every one of us daily and hourly" (Peirce 1903, p. 196). In claiming that "experience is our only teacher," Peirce demonstrated how learning is not only an essential but also an inevitable and frequently disarming aspect of experience:

In all the works on pedagogy that ever I read, - and
that have been many, big, and heavy, - I don't
remember that any one has advocated a system
of teaching by practical jokes, mostly cruel.
That, however, describes the method of our great
teacher, Experience. She says,

Open your mouth and shut your eyes

And I'll give you something to make you wise;

and thereupon she keeps her promise, and seems to take her pay in the fun of tormenting us. (Peirce 1903, p. 154)

Experience takes us by surprise, bewilders our categories of thought, and makes us learn. In contrast to William James, who at times seemed to limit experience to sensations only, Peirce advocates a broad notion of experience whereby a sensation is not the same thing as experience precisely because experience includes learning. So, Peirce holds a distinctive notion of experience that should be read in light of his three most basic phenomenological categories, "Firstness," "Secondness," and "Thirdness," which will now be explained.

Firstness is pure presence; it is what is regardless of anything else. It is "what stares one in the face, just as it presents itself, unreplaced by any interpretation, unsophisticated by any allowance for this or for that" (Peirce 1903, p. 147). Consider the color red: it emerges as a quality, a pure presence, or an attribute without reference to anything else. Redness is thus an illustrative example of firstness as the immediate presence of qualities.

Secondness is reaction; it concurrently contains some kind of pure presence and our perception of (or some other consequence of) this presence. Immediate perception is always an awareness of a relation: Secondness is a double consciousness that is aware of, on the one hand, the pure and vivid presence and, on the other hand, the perception of it. This might be, for instance, my amazement at the redness of a particular lipstick or my shock as an unseen person taps me on the shoulder. "Category the Second is the Idea of that which is such as it is as being Second to some First, regardless of anything else [...] That is to say, it is Reaction as an element of Phenomenon" (Peirce 1903, p. 160). But Secondness, as brute reaction, does not involve any mediation, transaction, or learning from experience.

Thirdness is transaction; it "essentially involves the production of [intelligible] effects in the world of existence" (Peirce 1903, p. 271). Thirdness is triadic, in the sense that it involves three relata. In the example cited above, these could be (i) the pure presence of the particular color red in the lipstick, (ii) the relation between that quality and my compulsion to notice it, and (iii) my offering some ongoing description of the lipstick as, for instance, "a striking color." Only at level (iii) do we reach the conceptual realm, or as it is sometimes called "the space of reasons." Thus it is important to note that despite the fact that Thirdness contains or assimilates Firstness and Secondness, it is by no way reducible to them. It is this sophisticated notion of Thirdness as a "generating multiple" (i.e., the step in numeric relatedness which brings into being all of logic - there is no need for a fourthness or higher) that supports Peirce's claim that experience is "the effect that life has produced upon habits" (Peirce 1903, p. 203). To put the same point another way, this third category elucidates the ways in which experience is "a forcible modification of our ways of thinking" [our emphasis] (Peirce 1906, p. 370). Or - to use Peirce's own words - we should at least hope that this is so, "since in that hope lies the only possibility of any knowledge" (Peirce 1903, p. 212).

\section{The Will to Learn}

Peirce maintains that "... there is a Thirdness in experience, an element of Reasonableness to which we can train our own reason to conform more and more" (Peirce 1903, p. 212). He thus eagerly promotes "the first rule of reason" - an ethos of inquiry - as a tool to guide and rectify habitual thinking. 
This "first rule of reason" is an intellectual interest, a curiosity, a dissatisfaction with what one already inclines to think, a wish to find things out, an aspiration to learn, and a passionate longing for understanding (Strand 2005). In many ways this pure motive is the only requirement for genuine education:

Upon this first, and in one sense this sole, rule of reason, that in order to learn you must desire to learn, and in so desiring not be satisfied with what you already incline to think, there follows one corollary which itself deserves to be written upon every wall of the city of philosophy:

Do not block the way of inquiry. (Peirce 1898, p. 178)

In a more or less subtle manner, Peirce here contests William James' famous paper "The Will to Believe" (1897), which had been published the year before. Since "the will to believe" a particular comforting proposition (such as that God exists) may "block the way to inquiry," Peirce suggests we should rather encourage "the will to learn" (1898, p. 171). In his argument for this, Peirce appeals to fallibilism, anti-dogmatism, and the fruitfulness of genuine doubt.

Fallibilism is the thesis that any of our beliefs may turn out to be false: "That we can be sure of nothing in science is an ancient truth" (1898, p. 179). But to Peirce, fallibilism is not only an epistemological call inherent in the self-amending procedure of the scientific method but also a call to a communal commitment to "the true scientific Eros"(1898, p. 107): a kind of honest life. On the one hand, Peirce stresses the necessity of each individual's dedicated commitment toward a universal "first rule of reason." On the other hand, he subordinates the individual scholar to the community of inquirers which constitutes each individual's best hope of moving closer to the truth.

However, Peirce admits that the social justification of beliefs is a double-edged sword. On the one hand - while holding the final consensus amongst the community of inquiry as a regulative ideal - Peirce sees social rectification and justification of beliefs at any given time as inevitable. On the other hand, he clearly takes a stance against the tendency of most people to subordinate their thinking to what they view as more authoritative ways of thought. To avoid the emergence of such dogmatism, it is vital to stress the fruitfulness of genuine doubt.

Genuine doubt is for Peirce the motive and motor of productive inquiries. In his fourth Cambridge lecture, he underlines that "science has been infected with overconfident assertion, especially on the part of [...] men who have been more concerned with teaching than with learning" (Peirce 1898, p. 179). As teachers need to have some confidence in the subject matter they teach and trust the ways in which they choose to teach it, they may overvalue the security of their beliefs. Consequently, the attitude of teachers is risky as they may not allow for genuine doubt. In contrast, the humble attitude of true learners is more fruitful: "you must be as a little child, with all the sincerity and simple-mindedness of the child's vision, with all the plasticity of the child's mental habits" (1898, p. 181).

In sum, "the will to believe" becomes less productive than "the will to learn" (Peirce 1898, p. 171) and thus is deprecated by Peircean pragmatist lights. The will to learn arises from doubt, which again should be conceived both as a subjective feeling and a seemingly falsified position. Thus, nurturing "the first rule of reason" is, first, about recognizing the subjective feeling of doubt and, next, about educating a community of critical thinkers who are able to question authoritative beliefs, know how to debunk them, and how to turn away from obiter dictum.

\section{Education}

Peirce never explicitly addressed education as an autonomous field of theory and practice (as did, for instance, Dewey). But he addressed the topic of higher education in a few minor publications. Peirce sums up a short text published in Johns Hopkins University Circulars this way:

In short, my view is the true one, a young man wants a physical education and an aesthetic education, an education in the ways of the world and a moral education, and with all these logic has 
nothing in particular to do; but so far as he wants an intellectual education, it is precisely logic that he wants; and whether it be in one lecture room or another, his ultimate purpose is to improve his logical power and his knowledge of methods. To this great end a young man's attention ought to be directed when he first comes to the university; he ought to keep it steadily in view during the whole period of his studies; and finally, he will do well to review his whole work in the light which an education in logic throws upon it. (Peirce 1882, p. 337)

"Logic" here denotes a broad study of general methods of inquiry, associated neither with formal logic nor with any specialized discipline. Accordingly, the study of logic should make students capable of keeping an overview, a superior perspective, and going beyond the strict rules and narrow borders of the artes liberales subject matters - taught at the university: "An intellectual education" should improve the student's "logical power and his knowledge of methods," regardless of which "lecture room" in which it happens. The students' devotion to the knowledge-producing culture of a university is therefore both the aim and the means of education.

So, Peirce should not be read as providing any narrow model of education or specific educational recipes. Rather, Peirce's philosophy should be interpreted as part of a long-lasting philosophical discourse which stretches from the ancient Paideia (rearing well-conducted citizens of the polis) through the medieval notion of Bildung (character formation) to modern conceptions of Emancipation. Consequently, Peirce's most significant contribution to the philosophy of education is not his explicit texts on higher education interpreted as guiding principles on what and how to educate. His most valuable contribution is rather his general logic, or theory of inquiry, and his semiotics.

It would seem that Peirce managed to bring his vision of logic to life in the classroom, as shortly after Peirce's death the testimonial "Charles S. Peirce as Teacher" was written by Joseph Jastrow, the noted experimental psychologist, whom Peirce taught at Johns Hopkins University in the mid-1880s. Despite 30 years having passed, Jastrow describes vividly and passionately his teacher's pedagogy and its effect on him. He states, "Mr Peirce's courses in logic gave me my first real experience of intellectual muscle", noting that Peirce did not merely lecture to him but trusted him to perform research alongside him by assigning tasks which excelled at "adding a moderate insight to a growing capacity" (Jastrow 1916, p. 724). This arguably places Peirce as an early leader in the now popular movement of "active learning” (Lizska 2013).

\section{Semiotics}

The point of departure of Peirce's semiotics which is the study of the action of signs and sign systems - is the axiom that cognition, thought, and even the human being are semiotic in their essence. All thoughts are in signs, and, like a sign, a thought refers to other thoughts and to objects in the world. The most central concepts of semiotics are "sign" and "semiosis."

A sign is simultaneously a medium and a mediator, a representation which (as we saw) itself is "an element of the Phenomenon" (Peirce 1903, p. 160). Its most characteristic feature is its triadic structure which, drawing on Peirce's key notion of Thirdness as "transaction," identifies every sign as a medium of both communication and creation:

I will say that a sign is anything, of whatsoever
mode of being, which mediates between an object
and an interpretant; since it is both determined
by the object relatively to the interpretant, and
determines the interpretant in reference to the
object, in such wise as to cause the interpretant to
be determined by the object through the mediation
of this "sign." (Peirce 1907, p. 410 )

Here Peirce notes that the mediating structure of the sign is the triadic relation which holds between sign, object, and "interpretant." For instance, if I own a lipstick with a color called "brave red," these words inscribed on the lipstick tube are the sign, the object is the lipstick's characteristic color, and the interpretant consists of all the ways in which the community continues to use these same words to describe this same color. If this process of sign-use continues over time, the sign can be said to be "living" not merely in a metaphorical sense. 
A further useful distinction in Peirce's semiotics holds between three kinds of sign: (i) symbols, which pick out their objects by arbitrary convention or habit; (ii) indices, which pick out their objects by unmediated "pointing"; and (iii) icons, which pick out their objects by resembling them (as Peirce put it: an icon's parts are related in the same way that the objects represented by those parts are themselves related). These three different kinds of signs may be understood as having different educative strengths insofar as icons excel at representing structure, thereby providing learners with a navigable road map of a subject matter and enabling them to see further connections of their own in what is taught, indices are what connect subject matters to the learner's own lived experience, and symbols enable generalizations to be made through all of the learner's experience (Legg 2017).

Learning processes may thus - at one analytical level - be seen as processes of sign interpretation which spread among the sign-using population insofar as they succeed at making the world more intelligible. Such processes include many different kinds of sign relations in which each relation is part of a complicated network of interpretations (or "theories") and interactive systems of actions. In other words, to Peirce, the dynamics of knowledge and learning consist in the flows of signs that press "upon every one of us daily and hourly." These actions of signs are $\operatorname{sem}(e)$ iosis:

By semeiosis I mean, an action, or influence, which is, or involves, a cooperation of three subjects, such as a sign, its object, and its interpretant, this thrirelative influence not being in any way resolvable into actions between pairs. (Peirce 1907, p. 411)

Peirce's notion of "semeiosis" - the action of signs - highlights the power of signs to move agents at a given time and to change their habits over time. This potency crucially involves Thirdness (not just mechanical causation, i.e., Secondness), because "no sign ever acts as such without producing a physical replica or interpretant" (Peirce 1903, p. 271). Consequently, semiosis is an intelligent, triadic action.

\section{Acts of Signs}

To philosophy of education, Peirce offers a model of mind and cognition which challenges much mainstream thinking, namely, semiosis (Strand 2013; Semetsky 2005). Thoughts are in the flows of signs, and, like a flow of signs, a thought refers to other thoughts and to objects in a world of change. We understand the world through signs; signs are our means to think about relations and objects. Signs give access to the local/global semiosphere in which we live and work, to the historically produced knowledge repertoire of our culture, and to the fast flows of information and communication distributed through social media and virtual networks (Legg 2013). Our understanding of the world is therefore always mediated through historically based and virtual signs and thus by the referential domain they elicit. Moreover, signs have the power to move agents and to change their habits. Dynamics of knowledge and learning are therefore in signs. But for these dynamics to be productive, sign processes have to be embodied (Strand 2014). Next, the conscious effects of such processes should be subject to self-control and pragmatic examination.

In sum, Peirce invites a shift in perspective from psychological processes of learning (as "inputting information") toward semiotic and pragmatic processes of communication and meaning-making. Needless to say, Peirce does not offer a theory of experiential learning or a didactics of experiential pedagogy. Rather, his distinct semiotics invites a sophisticated framework for further philosophical deliberations on education as semiosis.

\section{References}

James, W. (1897 [1992]). The will to believe. In G. E. Myers (Ed.), William James. Writings 1878-1899 (pp. 457-479). New York: The Library of America. 
James, W. (1907). Pragmatism: A new name for some old ways of thinking. Cambridge, MA: Harvard University Press.

Jastrow, J. (1916). Charles S. Peirce as a teacher. The Journal of Philosophy, Psychology and Scientific Methods, 13(26), 723-726.

Legg, C. (2013). Peirce, meaning and the semantic web. Semiotica, 2013(193), 119-143.

Legg, C. (2017). 'Diagrammatic teaching': The role of iconic signs in meaningful pedagogy. In Edusemiotics-A handbook (pp. 29-45). Singapore: Springer.

Lizska, J. J. (2013). Charles Peirce's rhetoric and the pedagogy of active learning. Educational Philosophy and Theory, 45(7), 781-788.

Peirce, C. S. (1882 [1958]). Logic and a liberal education. In P. P. Wiener (Ed.), Charles S. Peirce: Selected writings (pp. 336-337). New York: Dover Publications.

Peirce, C. S. (1898 [1992]). Reasoning and the logic of things. In K. L. Ketner (Ed.), Reasoning and the logic of things. The Cambridge Conferences Lectures of 1898 (pp. 105-268). Cambridge: Harvard University Press.

Peirce, C. S. (1903 [1998]). Harvard lectures on pragmatism. In N. Houser et al. (Ed.), The essential Peirce.
Selected philosophical writings. Vol. 2 (1893-1913) (pp. 133-241). Bloomington/Indianapolis, Indiana University Press.

Peirce, C. S. (1906 [1998]). The basis of pragmatism in phaneroscopy. In N. Houser et al. (Ed.), The essential Peirce. Selected philosophical writings. Vol. 2 (1893-1913) (pp. 360-370). Bloomington/ Indianapolis, Indiana University Press.

Peirce, C. S. (1907 [1998]). Pragmatism. In N. Houser et al. (Ed.), The essential Peirce. Selected philosophical writings. Vol. 2 (1893-1913) (pp. 398-433). Bloomington/Indianapolis, Indiana University Press.

Semetsky, I. (Ed.). (2005). Peirce and education. Special issue of Educational Philosophy and Theory, 37(2), pp. 151-254.

Strand, T. (2005). Peirce on education: Nurturing the first rule of reason. Studies in Philosophy and Education, 24(3), 309-316.

Strand, T. (2013). Peirce's new rhetoric: Prospects for educational theory and research. Educational Philosophy and Theory, 45(7), 707-711.

Strand, T. (2014). 'Experience is our great and only teacher': A Peircean reading of Wim Wenders' wings of desire. Journal of Philosophy of Education, 48(3), 433-445. 